University of Wollongong

Research Online

Faculty of Law, Humanities and the Arts Papers (Archive)

Faculty of Arts, Social Sciences \& Humanities

$1-1-2016$

Too big to fail: explaining the timing and nature of intervention in the Australian wool market, 1916-1991

Simon Ville

University of Wollongong, sville@uow.edu.au

David T. Merrett

University of Wollongong

Follow this and additional works at: https://ro.uow.edu.au/lhapapers

Part of the Arts and Humanities Commons, and the Law Commons

Research Online is the open access institutional repository for the University of Wollongong. For further information contact the UOW Library: research-pubs@uow.edu.au 


\title{
Too big to fail: explaining the timing and nature of intervention in the Australian wool market, 1916-1991
}

\begin{abstract}
From the early twentieth century, many Australian farm products have had their prices set by some form of intervention, often administered by a statutory marketing board. Wool was different: intervention, other than war-related exigencies, came much later and in a different mechanism, a reserve price scheme (hereafter RPS). The RPS that operated from 1970 until its collapse in 1991 has been roundly criticised. Four key elements explain the belated emergence and particular form of price controls: the specific characteristics of wool - its importance to the economy, its export orientation, and its non-perishability; the shifting locus of economic and political power in favour of small farmers; the declining influence of the wool-selling brokers and their associations; and the rise of statutory bodies and their capture by key figures supporting increased government participation.
\end{abstract}

\section{Keywords}

fail, big, too, 1916-1991, market, wool, australian, intervention, nature, timing, explaining

\section{Disciplines}

Arts and Humanities | Law

\section{Publication Details}

Ville, S. \& Merrett, D. (2016). Too big to fail: explaining the timing and nature of intervention in the Australian wool market, 1916-1991. Australian Journal of Politics and History, 62 (3), 337-352. 


\section{Too big to fail: explaining the timing and nature of intervention in the Australian wool market, 1916-1991}

\section{Abstract}

From the early twentieth century, many Australian farm products have had their prices set by some form of intervention, often administered by a statutory marketing board. Wool was different: intervention, other than war-related exigencies, came much later and in a different mechanism, a reserve price scheme (hereafter RPS). The RPS that operated from 1970 until its collapse in 1991 has been roundly criticised. Four key elements explain the belated emergence and particular form of price controls: the specific characteristics of wool - its importance to the economy, its export orientation, and its non-perishability; the shifting locus of economic and political power in favour of small farmers; the declining influence of the wool selling brokers' and their associations; and the rise of statutory bodies and their capture by key figures supporting increased government participation.

\section{Introduction}

From the early twentieth century, the price of many Australian farm products was set by some form of intervention, usually a statutory marketing board. ${ }^{2}$ Volatile commodity prices impacted heavily on the growing class of small farmer who had fewer resources to fall back on than their colonial forebears and who faced unstable cycles of boom, bust and wartime imperatives. Wool was different, however - centralised control came much later and took a

\footnotetext{
${ }^{1}$ We thank Shey Newitt for research assistance and staff at the University of Melbourne Archives for their help. Claire Wright kindly assisted with formatting the paper. Frank Bongiorno and Stuart Macintyre offered helpful feedback on an earlier draft. We are grateful for funding from the Australian Research Council under project DP 1095758. Two anonymous referees are thanked for their helpful comments.

${ }^{2}$ S. Harris, "Some measures of levels of protection to Australia's rural industries", Australian Journal of Agricultural Economics, Vol8, 2 (1964), pp. 124-44; P. Lloyd and D. MacLaren, "Assistance to Australian agriculture from Federation to World War II", The Australian Journal of Agricultural and Resource Economics, Vol58, 1 (2014), pp. 1-17; E. Sieper, Rationalising Rustic Regulation (St Leonards, 1982); W. M. Smith, The Marketing of Australian and New Zealand Primary Products (London, 1936); P. J. Lloyd, and D. MacLaren "Relative assistance to Australian and manufacturing since Federation", Australian Journal of Agricultural and Resource Economics, 59, 2 (2015), pp. 159-70.
} 
distinctive form with the introduction of a partial reserve price scheme in 1967 before one covering the entire clip in 1970. Apart from two episodes of war related intervention, the price of wool before this time reflected the intersection of the demand of the buyers and the supply of wool on offer at public auctions around Australia.

In this paper, we seek to explain why intervention in wool markets in twentieth-century Australia was different in form and timing from other commodity trades. Our analysis brings together some of the distinctive aspects of the economy of Australian wool with the changing face of its politics. Policy choices reflected, in part, wool's special place in the national economy through its role as the leading export, with no significant home market, and in its domination of the international raw apparel wool trade. Its heterogeneity as a product provided support for the persistence of broker-led auction sales and contributed to the political fault-lines that divided the wool industry lobby for decades. Its non-perishability kept alive the idea of a reserve price scheme.

In the following section of this paper we narrate the timeline of attempts to introduce central control of wool trading over half a century. The distinctive properties of wool and their influence on policy outcomes is explained in the subsequent section. The shifting locus of economic and political power in the industry in favour of small farmers at the expense of the more conservative graziers and the declining influence of the wool selling brokers' associations is then analysed. The exploitation of the rise of statutory bodies regulating the industry by several influential supporters of intervention provides the final chapter of the adoption of the RPS.

\section{The long history of attempts to control the market for wool}

Wool auctions developed around Australia in the last few decades of the nineteenth century replacing consignment to the London markets. At each of the major export cities - Sydney, Melbourne, Geelong, Adelaide, Brisbane, Perth - local woolbrokers jointly operated an open cry auction to dispose of most of Australia's massive wool crop, a system whose efficiency would be commended by overseas experts. ${ }^{3}$ It operated continuously to 1970 except for centrally administered schemes brought about by the exceptional conditions of two world wars and their aftermaths (Table 1).

${ }^{3}$ A. F. Du Plessis, The Marketing of Wool (London, 1931) 
Control of a supply of wool was a strategic imperative for the British government to clothe its troops and deny access to its enemies. Australian clips from 1916-1920 and 1939-1946 were acquired by Britain at prices that exceeded those prevailing in previous years. A number of other commodities - wheat, meat, dairy products, sugar, eggs, fruits and metals - were subject to similar arrangements in both wars. ${ }^{4}$

During the compulsory purchases, auctions were replaced by a system of appraisal whereby wool arriving into store was sorted into over 800 types or 'limitations' of wool whose value was set with reference to achieving an average price of $15.5 \mathrm{~d}$ per pound for the whole clip. Better quality wool received higher than average prices while lower quality wool received less. A similar procedure was followed in World War II when the average price was $13.4 \mathrm{~d}$ per pound from 1939 to May 1942, then increased to $15.5 \mathrm{~d}$ per pound. ${ }^{5}$

Shortages of shipping space during both conflicts meant that most of the wool acquired by the British government remained in Australia. This overhang of supply threatened to depress the price of the new season's wool that was no longer subject to acquisition. On 31 July 1921 the stock of carryover Australian wool stood at $1.489 \mathrm{~m}$ bales, which was in addition to the expected new wool coming onto the market during the $1921-22$ season of $1.85 \mathrm{~m}$ bales. $^{6}$ Addressing this problem brought about the next stage of intervention, an orderly disposal of large quantities of wool onto the market after the end of each war under the auspices of a multi-national selling organisation. Outstanding stocks of Australian wool owned by the British and Australian governments of $1.8 \mathrm{~m}$ and $9.6 \mathrm{~m}$ bales had been sold by 1924 and 1952 , respectively. $^{7}$

Various attempts to introduce a peacetime scheme were all unsuccessful but provoked contested and sometimes bitter debate within the wool trade about whether intervention in the marketing of wool was either desirable or feasible. The war-related interventions, while exceptional, were widely believed to have been a success, and served as a model of what

\footnotetext{
${ }^{4}$ Smith, Australian and New Zealand Primary Products; E. Scott, Australia during the War, Volume 11, The Official History of Australia in the War of 1914-1918 (Sydney, 1938); A. Watson and R. Parish, "Marketing agricultural products" in D. B. Williams, ed., Agriculture in the Australian Economy (Sydney, 1982), pp. 32652; A. Lloyd, "Agricultural price policy" in Williams, ed., Agriculture in the Australian Economy, pp. 353-82; ABS, Year Book of Australia, 1945 (cat. no. 1301.0, 1945), pp. 1105-13.

${ }^{5}$ K. Tsokhas, Markets, Money and Empire: The Political Economy of the Australian Wool Industry (Melbourne, 1990); C. Fyfe, Gentlemen's Agreements: Australian Wartime Wool Appraisements (Dalkeith, 1996); ABS, Year Book of Australia, 1945 (cat. no. 1301.0, 1945), p. 1106.

${ }^{6}$ E. Dyason, "BAWRA", Economic Record, Vol. IV, Supplement (1928), p.58.

${ }^{7}$ Dyason, "BAWRA", pp. 51-67; E. McCarthy, Wool Disposals 1945-52: The Joint Organization (Melbourne, 1967), pp. 111-12.
} 
might be achieved and the type of administrative framework required. ${ }^{8}$ The main steps in the process are shown in Table 2. The neatness of the table masks a messier litany of proposals and counter proposals emanating from the conferences of the wool growers associations and in state and federal parliaments, most of which were reported in the columns of the rural and metropolitan press.

Discussions about intervention were initiated by the overhang of stocks arising from the Imperial Purchase of wool during World War I and the operations of British Australian Wool Realisation Association (BAWRA), the body appointed to achieve an orderly disposal of the postwar surplus. Sir John Higgins, who had been chair of the Central Wool Council that administered the compulsory acquisition, was the leading interwar advocate of a mechanism to limit the supply of wool placed on the market.

Having failed in 1920 to persuade the growers and brokers of a plan to agree jointly on the volume of wool offered each season, he offered a more comprehensive and permanent scheme in 1922. Wool not reaching the minimum reserve price would be acquired by the 'central organization', BAWRA, to be re-offered when prices had returned to higher levels. In the face of fierce opposition from the conservative graziers and the brokers, the motion was defeated by a vote of its shareholders to wind up BAWRA's business.

In the wake of a calamitous fall in wool prices during the depression and the economic distress facing many growers, a committee of inquiry in 1932 recommended the introduction of a minimum price which was to be enforced through the application of a prohibition of the export of any wool sold at below that price. The plan was again rejected but the parameters of the debate had shifted. The government became increasingly engaged in the wool trade, setting up the Australian Wool Board (AWB Mark 1, 1936-53) in 1936 and participating in the International Wool Secretariat from 1937. ${ }^{9}$

The United Kingdom-Dominion Wool Disposals Ltd ('Joint Organization') was appointed to dispose of the much larger supply overhang following World War II. It completed its task of selling the stocks by 1952. Once again, arguments were presented to continue with an administrative scheme but the growers rejected the proposal by a decisive margin in August

\footnotetext{
${ }^{8}$ H. Sims, A Message from BAWRA (Sydney, n.d.); F. E. Hitchins, Skeins Still Tangled: Historic Survey Australian Wool Marketing 1952-1972 (Melbourne, 1972); F. E. Hitchins, Tangled Skeins: A Historic Survey of Australian Wool Marketing (Melbourne, n.d.)

${ }^{9}$ M. Abbott, "Promoting wool internationally: the formation of the International Wool Secretariat", Australian Economic History Review, Vol38, 3 (1998), pp. 258-78.
} 
1951. ${ }^{10}$ Following another sharp decline in wool prices through the second half of the 1950s, the Commonwealth government instituted a Wool Marketing Committee of Enquiry, which reported its findings in 1962. Arising from this was another proposal for an RPS. This time it was rejected only narrowly by the growers in December 1965.

However, this was not the end of the matter. The AWB released a Report in October 1967 whose terms of reference now included 'specific investigations of a reserve price scheme, acquisition schemes, central appraisement and private selling' ${ }^{11}$ The core proposals centred on lifting the returns to those small growers who sold less than four bales through the elimination of star lots, and by having their wool bulk classed and inter-lotted. ${ }^{12}$ To offset the delay of income resulting from these processes, growers would receive an 'average' price. A new Wool Marketing Authority would oversee this process whose powers included 'instruct[ing] brokers to withhold or withdraw lots within the averaging scheme from sale when ruling prices were at "unreasonably low levels." These lots would be released when price levels improved and, if not sold within the original price averaging period, would be bought by the authority at the 'state average price for that type'. ${ }^{13}$ A RPS covering around 40 per cent of the Australian clip had thus been introduced. ${ }^{14}$ A RPS covering all wool finally came into being in 1970 through new legislation creating the Australian Wool Commission rather than through a further plebiscite of growers. ${ }^{15}$

\section{Why the political economy of wool was different}

The pattern of government assistance varied significantly among agricultural products. Support in the inter-war years was mostly enjoyed by those industries that tended to be less focussed on export markets, such as dairying, fruits and eggs. ${ }^{16}$ It was easier to lift average prices received by growers in those industries in which import duties could increase the domestic price. Statutory marketing boards were responsible for exporting and the averaging

\footnotetext{
${ }^{10}$ McCarthy, Wool Disposals.

${ }^{11}$ I. Sturgess, "The Wool Board's second Report on Marketing: a review article", Australian Journal of Agricultural Economics, December,1968 p. 16.

${ }^{12}$ Star lots were small amounts offered for sale of up to four bales. These were expensive to market and attracted fewer buyers. Interlotting combined the lots of similar quality of several small growers.

${ }^{13}$ Sturgess, "Wool Board's second Report ", p. 18.

${ }^{14}$ C. Massy, Breaking the Sheep's Back: The shocking true story of the decline and fall of the Australian wool industry (St Lucia, 2011), p. 45.

${ }^{15}$ Australian Wool Commission Act, part III, "Functions and Powers of the Commission" no. 103, of 1970.

${ }^{16}$ Smith, Australian and New Zealand primary products; Sieper, Rustic Regulation.
} 
of domestic and export returns to growers. A distressed wheat industry received significant assistance in the 1930s. ${ }^{17}$ The farm industries receiving assistance post-World War II, however, expanded to include various exports such as sugar, rice, cotton, and dried fruit. ${ }^{18}$

Wool, though, was distinct from the other commodities in ways which limited the type of assistance that could be applied. It exported most of its output, wool was the nation's leading export over long periods of time, and it dominated the international wool trade. ${ }^{19}$ It was not possible for wool producers to increase their total receipts significantly by forcing local woollen mills to pay above the export price for wool. ${ }^{20}$ Few avenues were open to the wool industry to 'tax' local consumers. Import duties, therefore, would provide no benefit to the industry. While subsidies were possible, it made more fiscal sense to shift the burden to foreign buyers through an export tax, or, given the relatively low elasticity of demand, some form of price manipulation.

A RPS was more feasible for wool than nearly every other commodity. Its non-perishability enabled it to be stored for long periods as part of the manipulation of supply that the scheme would require. By contrast, the wheat acquired by the British government during World War I had suffered considerable damage and spoilage during storage. ${ }^{21}$ Moreover, wool was the only commodity for which there existed a large supply of storage capacity. The selling brokers had capacious warehouses and additional capacity was found by the Central Wool Committee during World War I as stocks grew. Their administration of the functions previously performed by the brokers - transportation, storage, appraisal of the value of each bale, and payment of the growers - as well as the operations of BAWRA in managing the sale of the stored wool, gave promise that the administrative machinery for a RPS was already in place. $^{22}$ Australia's leading role in the international wool trade and the relative inelasticity of supply additionally meant that holding buffer stocks and raising prices above market levels would not merely push market share to other producers.

\footnotetext{
${ }^{17}$ E. Dunsdorfs, The Australian wheat-growing industry, 1788-1948 (Melbourne, 1956), pp. 267-90; Lloyd and MacLaren, "Assistance to Australian agriculture", Table 1.

${ }^{18}$ Harris, " Australia's rural industries"; Lloyd, "Agricultural price policy"; Watson and Parish, "Marketing agricultural products"; G. Whitwell and D. Sydenham, A Shared Harvest: The Australian Wheat Industry, 1939. 1989 (South Melbourne, 1991); K. Anderson, P. Lloyd and D. Maclaren, 'Distortions to agricultural incentives in Australia since World War II', Economic Record 83, 263 (2007), pp. 468, 471.

${ }^{19}$ Australia produced a little more than a third of the world's apparel wool in the first half of the twentieth century (G. Blau, "Wool in the World Economy", Journal of the Royal Statistical Society 109 (1946), Table 4, pp. 184-5. Australia produced around 50 per cent of the world's merino wool.

${ }^{20}$ The local textile industry consumed only twelve per cent of the clip in 1947-48. Bureau of Agricultural Economics, Statistical Handbook of the Sheep and Wool Industry (Canberra, 1949), Table 76, p. 84.

${ }^{21}$ Scott, Australia during the War, pp. 588-92.

${ }^{22}$ Fyfe, Gentlemen's Agreements, chs 3, 11.
} 
Whether governments would be prepared to assist wool growers can be analysed through the lens of both public and private interest. The public interest argument derives from wool's critical importance to the economy, a situation captured in the phrase, 'Australia rode on the sheep's back'. ${ }^{23}$ Wool was Australia's leading export from the late nineteenth century until the 1970s. ${ }^{24}$ Its importance as an export was strengthened by the heavy external debt owed by Australian governments before World War II. ${ }^{25}$ The link between wool exports and the trade cycle weakened in the 25 years after World War II. ${ }^{26}$ However, its contribution to export earnings was central to the success of the federal government's management of the economy even as the structure of the economy moved towards manufacturing. ${ }^{27}$

The relevance of the wool industry to national prosperity and national solvency gave it special claims from a public interest point of view. Would the government stand by if the price of wool fell below its supply cost, and what was needed to pay growers to stay in business? The Commonwealth Wool Committee Enquiry study of the costs of production in 1932 found that the 'average' wool grower was not covering his working costs at the prevailing price of wool, and could not service his debts. The Report stated that if the industry is to thrive, the grower must receive an adequate return for a reasonable capital investment and be remunerated for his managerial services' ${ }^{28}$

If the price of wool had fallen further than its trough of 8d per pound in 1931 and recovered more slowly in the 1930s, what might have happened? The decline in the price of wheat in the Depression exacerbated by the ill-fated 'Grow more wheat campaign' increased political pressure for comprehensive intervention in the wheat industry. During the 1930s the federal government paid $£ 14.3 \mathrm{~m}$ in bounties and relief payment and another $£ 12 \mathrm{~m}$ in debt adjustment. $^{29}$ In 1948 the temporary Australian Wheat Board became permanent. ${ }^{30}$ Allowing the wool industry to fail would have been politically difficult as some of the wealthiest

\footnotetext{
${ }^{23}$ S. Stevens, "The importance of wool in Australia's national income", Economic Record, Vol. 26, 51 (1950), pp. 217-38.

${ }^{24}$ B. Pinkstone, Global Connections: A History of Exports and the Australian Economy (Canberra, 1992).

${ }^{25}$ C. Schedvin, Australia and the great depression: A study of economic development and policy in the 1920s and 1930s (Sydney, 1970).

${ }^{26}$ P. Cashin and C. McDermont, "'Riding on the sheep's back': examining Australia's dependence on wool exports", Economic Record, Vol. 78, 242 (2002), pp. 249-63.

${ }^{27}$ C. Schedvin, In reserve: central banking in Australia, 1945-75 (Sydney, 1992) and G. Whitwell, The

Treasury Line (Sydney, 1986) discuss the importance of trade balances in setting monetary and fiscal policy in the 25 years after World War II.

${ }^{28}$ Report of the Commonwealth Wool Inquiry Committee, The Australian wool industry (Canberra, 1932), para. 123.

${ }^{29}$ Dunsdorfs, Australian wheat-growing industry, pp. 279-91.

${ }^{30}$ Whitwell and Sydenham, Shared Harvest, pp. 50-64.
} 
people in Australia were the powerful 'squatters' who farmed great estates. If wool was too big to save through the public purse, though, governments may have hoped that the growers would find a solution to save themselves. The politicians, like the wool growers, were oblivious to the risks embedded in the proposed model, a RPS, despite a chorus of disapproval from the emerging profession of agricultural economics from the 1960s.

While the lens of public interest suggests the likelihood of strong support for wool producers, the private interest was more problematic. Producers co-operate through political markets to extract rents from consumers forced to pay higher prices. Farm price volatility has encouraged governments to exchange 'transfers' for political support despite evidence from economists of the inefficiencies this has created. ${ }^{31}$ The private interest theory of regulation suggests that it was rational for the farmers of particular commodities to devote resources to persuading governments to meet their demands as the benefits accrued to them, while the per capita costs of the 'rents' were comparatively low when dissipated across all consumers. ${ }^{32}$ Given that the 'consumers' of wool were largely foreign buyers with limited constituency, the political case for intervention becomes more persuasive. Some groups, however, are better placed than others to extract rents. ${ }^{33}$ Another important feature of the wool industry - its heterogeneity - detracted from the ability of producers to extract policy rents. ${ }^{34}$

Heterogeneity derived from the nature of wool itself and the many contexts in which it was produced in twentieth-century Australia. Australia's sheep population was overwhelmingly merino with a minority of cross-breed types. Within those broad categories, there were numerous sub-breeds that were pastured across widely differing climatic regions. Farming practices also varied among producers, affecting the qualities of the wool produced. There was further heterogeneity within the wool clip by parts of the fleece that classers distributed into bales. The land subdivision policies of the second half of the nineteenth century, the opportunities for mixed farming brought about by refrigeration, together with returning soldier settler schemes in the twentieth increasingly created very different classes of wool

\footnotetext{
${ }^{31}$ K. Anderson, G. Rausser and J. Swinnen, "Political economy of public policies: insights from distortions to agricultural and food markets", Journal of Economic Literature, 51, 2 (2013) p. 449; D. A. Irwin, Free Trade under Fire (Princeton, 2002).

${ }^{32}$ G. Stigler. 1971. The theory of economic regulation. Bell Journal of Economics and Management Science 2 (spring), pp. 3-21.

${ }^{33}$ See R. E. Baldwin and F. Robert-Nicoud, 'Entry and asymmetric lobbying: why governments pick losers, Journal of the European Economic Association 5, 5 (2007), pp. 1064-93.

${ }^{34}$ E. La Ferrara, "Inequality and group participation: theory and evidence from rural Tanzania." Journal of Public Economics 85, 2 (2002), pp. 235-73.
} 
producers. Essentially, this was a bifurcation between the large graziers who were among the earliest settlers and the range of smaller scale producers that emerged from these policies.

The highly heterogeneous character of wool required a very different form of marketing system from most other commodities that were sold directly to merchants or processors such as meat or dairy products. Only wool employed selling brokers as intermediaries between the growers and buyers who provided a comprehensive set of marketing services. They received wool into store, weighed and catalogued it, permitted buyers to inspect sample bales prior to auction, and conducted the auctions. Brokers had built up great knowledge of the complex wool trade and had invested in large warehouse facilities. ${ }^{35}$

Deep divisions existed within the wool growing community about the best form of marketing. The large scale specialist wool growers, the 'graziers', favoured the auction system operating without government intervention. Smaller scale growers, an increasing proportion of whom also grew wheat and/or raised beef and dairy cattle, called for assistance. These different perspectives flowed from the economic position of each group. The graziers had the resources to await payment from the London sales and to withstand fluctuations in the prosperity of the industry. Many had long standing relationships with brokers and stock and station agents who provided them with lines of credit. They also benefited from paying lower sales commissions to their agent in reflection of the economies of scale of handling larger consignments. ${ }^{36}$ By way of contrast, the smaller scale growers had fewer resources to enable them to ride out poor seasons and they paid relatively more per bale to the brokers. It was the smaller and indebted growers who suffered most during the Depression. ${ }^{37}$ In contrast to the graziers, some smaller growers harboured a grievance against the 'middleman' broker whose charges for marketing services seemed exorbitant. ${ }^{38}$ Woolgrowers had a saying: 'I shear the sheep, and my agents shear me'. ${ }^{39}$ Any sharp fall in commodity prices fuelled calls for

\footnotetext{
${ }^{35}$ D. Merrett, S. Morgan and S. Ville, "Industry associations as facilitators of social capital: The establishment and early operations of the Melbourne Woolbrokers' Association", Business History, Vol. 50, 6 (2008), pp. 78194; D. Merrett and S. Ville, "Institution building and variation in the formation of the Australian wool market", Australian Economic History Review, Vol. 53, 2 (2013), pp. 146-66.

${ }^{36}$ D. Merrett and S. Ville, "Industry Associations and non-competitive behaviour in Australian wool marketing: evidence from the Melbourne Woolbrokers' Association, 1890 - 1939", Business History, Vol. 54, 4 (2012), pp. $514 ; 517-22$.

${ }^{37}$ Commonwealth Wool Inquiry Committee, The Australian wool industry, p. 15

${ }^{38}$ W. Dunn, "Second conference of producers \& consumers" (Bathurst, 1931) Dunsdorfs, The Australian wheatgrowing industry, pp. 221-27.

${ }^{39}$ A. Sinclair, A Clip of Wool from the Shearing Shed to Ship (Sydney, 1913), 2nd ed., p. 13.
} 
assistance. The risk that larger graziers would be able to buy out smaller farmers in difficult times without support also put the two groups at loggerheads over policy. ${ }^{40}$

\section{The shifting politics of the wool industry}

\section{The growing influence of small farmers}

The economic bifurcation of the industry described above played out in the political context. Wool growers were further divided in terms of ideology. The graziers' political views had been forged in the late nineteenth century. In the 1890s they formed political associations, such as the overarching Pastoralists' Federal Council, which was renamed the Graziers' Federal Council in 1919, to defend themselves against demands from shearers, carters and maritime unions for higher pay. An initial objective of the United Graziers' Association of Queensland was the right to 'freedom of contract' ${ }^{41}$ Liberal economic ideology in the labour market was carried over to a 'hands off' attitude in the organization of product marketing. As Australian politics was reshaped by the emergence of the Australian Labor Party in the early twentieth century, the conservative side of politics split into an urban party of capital and, after World War I, a Country Party to represent those in the 'bush'. ${ }^{2}$ The graziers were united with the urban elite and its political parties through commercial relationships, social networks, and sectarian ties. ${ }^{43}$ Farmers found a political voice through the formation of numerous commodity-based farm associations and the Country Party which quickly enjoyed electoral success in many states as well as federally. ${ }^{44}$

The smaller wool growers were to win the battle for political influence. Crisp notes that soon after 1900 '...farmers were soon threatening to be able to out-shout the squatters. ${ }^{45}$ Farmers showed a remarkable propensity to organize to protect and advance their interests.

\footnotetext{
${ }^{40}$ Anderson et al "Distortions to agricultural incentives", p. 478.

${ }^{41}$ R. Kerr, Freedom of Contract: A History of the United Graziers' Association of Queensland (Brisbane, 1990), p. 7.

${ }^{42}$ B. Graham, The Formation of the Australian Country Parties (Canberra, 1966); U. Ellis, A History of the Australian Country Party (Melbourne, 1963).

${ }^{43}$ B. Graham, "Graziers in Politics, 1917-29" in A. Barnard, ed., The Simple Fleece: Studies in the Australian Wool Industry (Melbourne, 1962), pp. 592-602, pp. 592-602; S. Encel, Equality and Authority: A Study of Class, Status and Power in Australia (Melbourne, 1970), ch. 16.

${ }^{44}$ W. Hancock, Australia (London, 1930), pp.232-38. K. O. Campbell, "Australian farm organizations and agricultural policy", Australian Journal of Agricultural Economics, Vol. 10, 2 (1966), pp. 112-27; Graham, Formation of the Australian Country Parties; C. A. Hughes and B. Graham, A Handbook of Australian Government and Politics 1890-1964 (Canberra, 1968).

${ }^{45}$ L. Crisp, The Parliamentary Government of the Commonwealth of Australia (London, 1949), p. 125.
} 
Associations grouped around commodities popped up like mushrooms within and across states and came to forge national bodies. ${ }^{46}$ Regular improvements in infrastructure, primarily transport provision and the growth of mass media, reduced the collective action costs for large numbers of rural farmers. ${ }^{47}$ Growers felt that they deserved protection from volatile prices and rapacious middlemen: the solution was cooperative marketing arrangements with the assistance of the state. ${ }^{48}$ A willing political handmaiden was found in the Country Party whose policies with respect to marketing reflected the wishes of producer bodies placed in charge of statutory marketing authorities. The evolution of the various associations representing wool growers shows that the membership of those representing the smaller groups was significantly greater than those representing the graziers after World War II. The decisive break came in 1939 with the establishment of a national body, the Australian Wool and Meat Producers Federation (hereafter AWMPF), from a number of organizations which had formed in the 1930s. By the mid-1960s, the 46,000 members of the AWMPF produced 60 per cent of Australia's wool. By contrast, the graziers, whose national body became the Australian Woolgrowers' and Graziers' Council in 1960, had less than 25,000 members. ${ }^{49}$

While the numbers and influence of the small and mixed farmers rose, the position of the graziers in the wool industry was undergoing a slow decline. The largest woolgrowers were in retreat. In 1919-20 flocks with more than 10,000 sheep accounted for 18 per cent of all flocks, by 1939-45 this number had fallen to 14 per cent before collapsing to six per cent in 1960. In 1930, 30 per cent of wheat farms ran sheep. This number had risen to over 80 per cent by $1960 .^{50}$ The drought and price falls in the 1960s marked a decisive break in the fortunes of second and third generation grazier dynasties. Alec Morrison notes 'State and federal government policies were stacked against them - closer settlement, land tax and death duties were all designed to break up the big family estates, and were too successful in doing so. Taxation laws in respect of tax on undistributed profits precluded family firms from accumulating reserves to be held against tough times' ${ }^{51}$

\footnotetext{
${ }^{46}$ Campbell, "Australian farm organizations"

${ }^{47}$ Anderson, Rausser, and Swinnen, 'Political Economy of Public Policies', p. 455.

${ }^{48}$ Dunn, "Second conference of producers \& consumers", pp. 17-19.

${ }^{49}$ E. Daw, "Woolgrowers and wool marketing", Australian Quarterly, Vol. 37, 2 (1965), pp. 11-24, pp. 12-13.

${ }^{50}$ Bureau of Agricultural Economics, Statistical Handbook of the Sheep and Wool Industry (Canberra, 1949), Tables 21, 23 and 25; Bureau of Agricultural Economics, Supplement to the Statistical Handbook of the Sheep and Wool Industry (Canberra, 1964), Tables 24A and 25.

${ }^{51}$ A. Morrison, When Wool was King: The Inside Story of Australia's Wool Industry (Milsons Point, 2009), p.152.
} 


\section{The declining role of the wool selling brokers' associations}

The wool brokers' associations and their member companies, the likes of Dalgety, Goldsbrough Mort, and Australian Mercantile Land and Finance, had the most to lose from the end of the auction system, of which they were the central coordinators, or it becoming an adjunct to an administrative system of determining price. They campaigned vigorously to persuade growers to vote against all the proposals for intervention. Faced with the intervention precedent set by World War One and confronted by the growing power of the small farmer lobby ignited by diminishing cost-price margins, they lacked the leadership and organisational structure to see off the challenge to their traditional leadership of the wool trade.

The National Council of Wool Selling Brokers Associations (NCWSBA) did not provide a platform for a strong leader. This national body only came in to being at the end of World War One, a quarter of a century after most of its constituent regional associations. It had little authority over the local associations who conducted the auctions and with whom it was often in disagreement. ${ }^{52}$ Infrequent meetings amongst its executive, comprised of second tier management ranks from the big pastoral houses and separated by long distances, and the rotation of the chairmanship between the large Anglo-British firms from Sydney and Melbourne, created little social capital that may have forged a more cohesive group with a clear vision of its future and purpose.

The brokers had no option but to work with the government-appointed Central Wool Committee during and immediately following both World Wars under the appraisal system. The quarrel concerned what would come next - whether prices should be 'managed' or left to the dictates of the market according to the trade's custom and practice. Although proposals to create a RPS in the twenties were defeated, the role of the brokers irrevocably altered as growers increasingly played a direct role in industry policy, no longer mediated through the brokers. Participation in the Australian Wool Council (AWC) from 1920 gave the growers a seat at the table. While its principal objective was to determine allocations for the coming season, the growers used the AWC as a forum to press their claims for better terms and conditions from the brokers for the services provided. They were no longer simply clients but partners.

\footnotetext{
${ }^{52}$ Sydney's Association which sold more wool than any other centre was a constant thorn in its side. University of Melbourne Archives, Accession 106, NCWSBA, Minutes, 19/6/1936, 312-16.
} 
Increasingly, the brokers felt that 'in a lot of little ways the Growers were encroaching on our preserves'. ${ }^{53}$ The growers broke ranks on a range of issues. For instance, they approached the government to give the necessary authority to both research and promotion through the creation of the AWB (Mark 1) ${ }^{54}$ and the International Wool Secretariat. ${ }^{55}$ Dalziel Kelly, chairman of the Australian Woolgrowers' Council, claimed that he had drafted the bill creating the AWB (Mark 1) and had been instrumental in the formation of the International Wool Secretariat. ${ }^{56}$ In 1931 the growers approached the government to establish an enquiry into the wool industry which recommended that a RPS be instituted. Moreover, brokers were offered far fewer representatives than the growers on the proposed industry body, the Commonwealth Wool Executive. To add insult to injury, Sir Graham Waddell, acting chairman of the AWC, had directly approached the government in October 1934 seeking a guarantee of funding to support a floor price of $£ 6$ per bale. ${ }^{57}$ The entente cordiale was long over.

The lack of decisive leadership and direction by the NCWSBA itself, reflecting its decentralised structure, made matters worse. By avoiding overt contact with government they surrendered influence to the growers. They made a fatal mistake in 1934 by refusing an invitation from Sir Graham Waddell, chairman of AWC, to join with the growers in a deputation to the Prime Minister. The brokers still held to the view that any involvement by the government in the wool trade should be avoided. Sir Frank Young, President of NCWSBA, argued that it was 'very unfortunate that the Government has been brought into the Wool Trade [by creating the AWB]... [there] was a danger of this developing into more general Government control, ${ }^{58}$ The shortcomings of the brokers and their associations were further exposed when they attempted their own form of buffer stock control to offset intraseason price falls by limiting offerings and/or cancelling auctions, particularly in 1924-25, 1931-32, 1933-34 and 1937-38. The mixed results confirmed to growers that the brokers could not deliver a smoothing of the price of wool. They lacked accurate information about the wider aspects of the wool market such as production in other countries, stocks in manufacturing countries, demand from the textile industry, or the supply of substitute fibres

\footnotetext{
${ }^{53}$ NCWSBA, Minutes, 14th February 1938, p. 3.

${ }^{54}$ Wool Publicity and Research Act, No. 24 of 1936.

${ }_{55}$ Abbott, "Promoting wool internationally".

${ }^{56}$ NCWSBA, Minutes, 9th June 1935, p. 389; A. Barnard, "Kelly, Sir George Dalziel (1891-1953)", Australian Dictionary of Biography, Vol. 9, 1 (1983), pp. 555 - 6.

${ }^{57}$ NCWSBA, Minutes, $7^{\text {th }}$ December 1932, p. 245, 9th August 1934, pp. 163-65; 10th August 1934, p. 167.

${ }^{58}$ NCWSBA, Minutes, $23^{\text {rd }}$ September 1934, p. 343, $10^{\text {th }}$ June 1936 , p. 403.
} 
such as cotton and, from the 1930s, synthetics and were ignorant of the idea of price elasticises.

The brokers faced similar pressures after World War Two but were by now a much diminished force. By the early 1950s the brokers were aware that their organization had 'lost [its] former prestige' and that it was being 'batted from pillar to post' ${ }^{59}$ While the brokers could communicate their views about wool marketing directly to individual growers through their agents and by letter during the various referendum campaigns in 1951 and 1965, they had minimal political influence. Despite the claims of Higgins and some growers that they had operated a high cost model, brokers had struggled to maintain revenues throughout the difficult interwar years as they faced increased competition from co-operative brokers and strong pressure from growers to reduce fees and commissions. Regional pressure to establish new selling centres, following their temporary World War Two expansion, threatened the scale efficiencies of the traditional auction locations. Large value, co-ordinated investments were required in facilities such as new warehouses outside the CBDs and in new services such as testing houses and futures markets. All of these initiatives would have necessitated collective investments by the brokers. Unfortunately, the structure of the wool-selling brokers' associations rendered such action improbable. Altering the Constitution in 1962 to include meetings of the chief executives of the parent companies, as a Board of Principals, was a case of too little far too late. Consolidation and diversification from the industry amongst these companies by the 1960s inevitably diminished their interest in wool. ${ }^{60}$

\section{The rise of statutory bodies and the role of personality.}

The wool trade became increasingly populated by a range of official bodies stepping into the void left by the brokers, encouraged by growers' representatives, and forming part of the expanded role of government in industry and macroeconomic policy in mid twentieth-century Australia. As the nation's most important export industry, wool particularly attracted notice. The AWB (1936) and participation in the International Wool Secretariat from 1937, mentioned above, were early examples of such bodies. AWB's functions were 'the improvement of the production of wool in Australia', and 'the increase and extension, by

\footnotetext{
${ }^{59}$ NCWSBA, Minutes, $22^{\text {nd }}$ April 1952, p. 43

${ }^{60}$ S. Ville, The Rural Entrepreneurs: A history of the stock and station agent industry in Australia and New Zealand (Cambridge, 2000), pp. 50-52.
} 
publicity and research or any other means, of the use of wool throughout the world.' To this end it had access to a Wool Publicity and Research Fund, which was financed by receipts of 6d per bale raised by the Wool Tax Act 1936 .

Over time the resources available to the statutory bodies and the scope of their activities continued to widen. Levies imposed on the growers gave rise to a growing stream of revenues. ${ }^{61}$ Grower levies were increasingly augmented by government guarantees of borrowing, capital injections and monies from consolidated revenues. ${ }^{62}$ The government also provided capital for the Australian Wool Testing Authority which began in $1957 .{ }^{63}$ The Australian Wool Realization Commission, the local arm of the Joint Organsiation, lived on despite the defeat of the 1951 referendum. Some of its resources, the large stock of wool stores accumulated during the war, ${ }^{64}$ along with the Wool Statistical Service, were transferred to the new Australian Wool Bureau in 1953. The latter now replaced the brokers in the estimation of the size of the clip and allocation of wool to be offered at auction.

Following the Inquiry into the wool industry in 1961, the Australian Wool Bureau was replaced by the AWB (Mark 2) in 1963. ${ }^{65}$ The game had decisively changed as the powers of this new authority were to encompass marketing as well as promotion. To this end, the Board was to liaise with the newly-created Australian Wool Industry Council (AWIC) for the purposes of introducing a reserve price scheme, and a Wool Marketing Committee was created to prepare a plan. With the passage of the Wool Industry Act 1970 and the introduction of the Australian Wool Commission Act 1970 the passage to a RPS was complete.

Critical to this last phase of the adoption of an RPS for wool was that fact that its supporters, especially the AWMPF, had the inside running as they worked within the generously resourced statutory bodies whose policies they could influence and that provided access to senior politicians and bureaucrats. The timing of AWMPF's birth in 1939 was most fortuitous as the control of wool marketing during the war and immediate post-war years provided the AWMPF with the opportunity to entrench itself within the statutory bodies. Representatives of the AWMPF were given places on the Central Wool Committee and on the Australian

\footnotetext{
${ }^{61}$ ABS, Year Book Australia, 1966 (cat. no. 1301.0, 1966), pp. 52 and 944; NCWSBA, Wool Review 1965/66, p. 7.

${ }^{62}$ Wool Use Promotion Act 23 of 1952, Wool Industry Acts, 99 of1962 and 24 of 1964.

${ }^{63}$ Australian Wool Testing Authority Act, 1957.

${ }^{64}$ Wool Stores Act, 91 of 1953.

${ }^{65}$ Wool Industry Act, 99 of 1962.
} 
Wool Realization Commission in 1940 and 1945 respectively. Eric Hitchins, AWMPF president, was actively involved in the conferences that led to formation of the Joint Organization and in the discussions about the proposal to continue its operation afterwards. ${ }^{66}$ In keeping with customary practice of the relationships between producers and the Country Party, representatives on these boards were drawn from 'nominees of the relevant commodity organizations' whose resultant close links with politicians and bureaucrats gave them a privileged position in the formation of agricultural policy. ${ }^{67}$ As Encel noted, Country Party members or 'farmers' representatives are frequently able to hold ministerial portfolios which enable them to advance the interests of farmers by direct administrative action' ${ }^{68}$

This close nexus between producers, politicians, and public bodies had the effect of bringing into coalition three powerful personalities from across these three sectors who, Charles Massy has argued, played a key role in the manoeuvring of the 1960s to bring the RPS to fruition. While the brokers languished from lack of leadership, the proponents of a reserve price scheme were led in the post-war period by three 'knights': Sir William Archer ('Bill') Gunn, Sir John Crawford, and Sir John ('Black Jack') McEwen. Gunn, from a pastoral background and Chairman of AWB from 1958, was a 'formidable operator, full of cunning and political savvy' who particularly understood the critical role of the statutory bodies. In Massy's view, his 'legacy was to convert both the AWB and the IWS from statutory appendages to interventionist vehicles'. ${ }^{69}$ Crawford was a highly respected and influential public servant trained in agricultural economics. He was appointed as the first Commonwealth Wool Advisor in 1950, a position that strengthened the link between the AWB and the government, particularly as he was a senior bureaucrat with close connections to the Cabinet. In the same year, he became Secretary of the Department of Commerce and Agriculture, and of the reorganised Department of Trade in 1956. In 1962-4 he chaired the Australian Wool Industry Conference. His opinions provided credibility and gravitas to the influence of McEwen and the hustling of Gunn. McEwen, leader of the Country Party from 1958, was Crawford's minister at Commerce then Trade, positions he held for over two decades. McEwen's strong belief in agricultural assistance was informed by his experiences as a soldier settler (although successful himself) and witnessing the impact of the interwar

\footnotetext{
${ }^{66}$ Hitchins, Tangled Skeins; Fyfe, Gentlemen's Agreements; McCarthy, Wool Disposals.

${ }^{67}$ Campbell, "Australian farm organizations", pp. 117-120.

${ }^{68}$ Encel, Equality and Authority, p. 317.

${ }^{69}$ Massy, Breaking the Sheep's Back, p. 20, p. 16.
} 
depression. He used his formidable political skills to exploit the coalition's small majorities and the cost-price squeeze of the 1960s in support of the reserve price scheme.

\section{Conclusion}

The wool industry has occupied a central place in modern Australian history. It created enormous wealth for large squatters-cum-pastoralists in the nineteenth century. By the twentieth century, profits and changes in property regimes had lured many smaller farmers into the industry and attracted the attention of policy makers and economic thinkers aware of its importance for long term development in Australia. Like all commodities, wool suffered from the instability of fluctuating supply and demand; but the stabilising solution deployed for other farm products - statutory marketing boards - was unsuited to a product of wool's heterogeneity. It had apparently found its own solution late in the nineteenth century - a broker led auction system - but this was failing under the pressure of economic uncertainty and political change.

The result was a broad-ranging fifty-year debate about the future of wool marketing in Australia, which infused its way through the mainstream of economic and political debate by encompassing the views of industry leaders, politicians, public servants, and economists. At length, it produced a unique experiment for Australia - a reserve price scheme. The scheme failed within twenty years. In this paper, we have described the long tortuous pathway to an RPS and analysed why it ultimately produced a scheme that was unsuccessful. Throughout its evolution, the weight of economic thinking was opposed to an RPS. However, this came up against a political environment in mid-century that was increasingly receptive to the idea, particularly through the growing number of small farmers, most vulnerable to market fluctuations, with their emerging industrial representation, the AWMPF, and a political voice that was growing louder, the Country Party. The traditional laisser-faire forces of the industry, graziers and brokers, were sidestepped by increasing support for industry statutory bodies after World War Two. Even then, it took a coalition of powerful personalities across growers, politics and officialdom - Gunn, McEwen and Crawford - united in their belief in an RPS and connected through statutory bodies and the Country Party - to drag the RPS over the line. 
The importance of the wool industry in Australia also mattered to this outcome. Massy has argued that the RPS's failure lay in the choice by 'wool industry leaders to take a political and not a commercial path to meet competitors'. Critics of the economics of such schemes

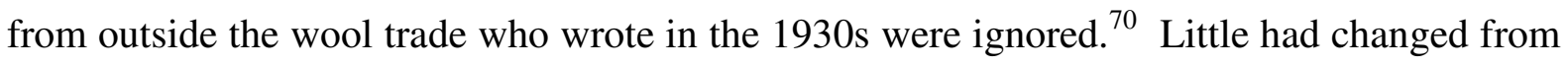
the 1960s onwards 'when most of the arguments advanced by the fierce participants on the two sides had little economic substance'. ${ }^{71}$ While this is true, the willingness of politicians and public servants to listen to the industry also derived from a belief that the massive wool trade was too big to fail.

\footnotetext{
${ }^{70}$ J. B. Brigden, 'The marketing of wool', Addendum No. 1, Report of the Commonwealth Wool Inquiry Committee (Canberra, 1932), pp. 52-58; L. G. Melville, 'Wool stabilisation', Sydney Morning Herald, 13 July 1931, p. 9, and Du Plessis, Marketing of Wool.

${ }^{71}$ F. Gruen, "A quarter of a century of Australian agricultural economics - some personal reflections", The Australian Journal of Agricultural and Resource Economics, Vol. 42, 2 (1998), pp. 177-190, p. 185.
} 
Table 1. Operations of Australian Wool market 1900-1991

\begin{tabular}{|l|l|}
\hline Date range & Method of selling \\
\hline 1890 -1916 & Auctions \\
\hline $1916-20$ & Compulsory purchase at fixed price \\
\hline $1920-1924$ & Mix of auction of new wool and orderly disposal of surplus war wool \\
\hline $1925-1938$ & Auctions \\
\hline $1939-1945$ & Compulsory purchase at fixed price \\
\hline $1946-1950$ & Mix of auction of new wool and orderly disposal of surplus war wool \\
\hline $1951-1967$ & Auction \\
\hline $1967-70$ & Mix of RPS for small lots and auctions for the rest \\
\hline $1970-1991$ & Reserve price scheme \\
\hline $1992-$ & Auctions \\
\hline
\end{tabular}


Table 2. Proposals for intervention

\begin{tabular}{|c|c|c|}
\hline Date & Scheme & Result \\
\hline $\begin{array}{l}\text { March } \\
1920\end{array}$ & $\begin{array}{l}\text { Australian Wool Council. } \\
\text { Proposed to return to auction but with the } \\
\text { power to withhold wool from sale to } \\
\text { influence price. Growers to pay levy of } \\
1 \% \text {. To operate for one season only, } \\
1920 / 21 \text {. }\end{array}$ & $\begin{array}{l}\text { Defeated by growers' vote } \\
74.9 \% \text { of votes cast in favour, } \\
\text { required } 75 \% \text { for acceptance. }\end{array}$ \\
\hline May 1921 & $\begin{array}{l}\text { Directors of BAWRA appeal to } \\
\text { Commonwealth government to set a } \\
\text { minimum export price. }\end{array}$ & $\begin{array}{l}\text { No wool to be exported below 8d } \\
\text { per pound, May-November } 1921 .\end{array}$ \\
\hline $\begin{array}{l}\text { August } \\
1922\end{array}$ & $\begin{array}{l}\text { Conference between BAWRA and } \\
\text { growers. } \\
\text { Higgins proposes four 'plans'. Plan } 4 \text { to } \\
\text { 'guarantee a minimum price'. }\end{array}$ & $\begin{array}{l}\text { Growers agree to Plan } 4 \text { which } \\
\text { brokers oppose. }\end{array}$ \\
\hline $\begin{array}{l}\text { October } \\
1922\end{array}$ & $\begin{array}{l}\text { Extraordinary meeting of BAWRA. } \\
\text { Higgins proposes extension of plan } 4 \text { to } \\
\text { utilise } £ 16 \mathrm{~m} \text { of undistributed profits as } \\
\text { capital. Promise of lower marketing costs } \\
\text { through 'central organization'. }\end{array}$ & $\begin{array}{l}\text { December } 1922 \text { meeting only } 15 \text { of } \\
800 \text { supported. }\end{array}$ \\
\hline June 1925 & $\begin{array}{l}\text { Higgins presents similar plan to the } \\
\text { Graziers' Federal Council. }\end{array}$ & No action. \\
\hline June 1931 & $\begin{array}{l}\text { Higgins presents similar plan to Empire } \\
\text { Wool Conference in Melbourne. }\end{array}$ & $\begin{array}{l}\text { Referred to committee which did } \\
\text { not meet. }\end{array}$ \\
\hline 1932 & $\begin{array}{l}\text { Commonwealth Wool Inquiry Committee } \\
\text { proposes formation of a Commonwealth } \\
\text { Wool Executive of representatives of } \\
\text { growers and brokers to set minimum } \\
\text { prices. Government to prohibit export of } \\
\text { wool below that price. The Executive to } \\
\text { 'confer with the Commonwealth } \\
\text { Government to secure necessary funds'. }\end{array}$ & $\begin{array}{l}\text { Lobbying by conservative graziers } \\
\text { and selling brokers prevents } \\
\text { government action. }\end{array}$ \\
\hline
\end{tabular}




\begin{tabular}{|l|l|l|}
\hline 1951 & $\begin{array}{l}\text { Proposed continuance of Joint Operation, } \\
\text { by a statutory body involving the UK } \\
\text { government, which withdrew, New } \\
\text { Zealand and South Africa. Australian } \\
\text { contribution of £59m through through a } \\
\text { grower levy of 71/2\% and government } \\
\text { guarantee to cover shortfall. }\end{array}$ & $\begin{array}{l}\text { Defeated 'no' votes to } \\
16,310 \text { 'yes'. }\end{array}$ \\
\hline 1965 & $\begin{array}{l}\text { Proposal for AWB to operate a RPS. } \\
\text { Growers to contribute capital by levy, } \\
\text { supplemented by bank loans and } \\
\text { government guarantee. }\end{array}$ & $\begin{array}{l}\text { Defeated 59,235 'no' votes to } \\
51,386 \text { 'yes' votes. }\end{array}$ \\
\hline 1967 & $\begin{array}{l}\text { AWB introduces RPS covering lots of } \\
\text { four bales or less. }\end{array}$ & $\begin{array}{l}\text { No plebiscite. Statutory body has } \\
\text { powers to act. }\end{array}$ \\
\hline 1970 & $\begin{array}{l}\text { Australian Wool Commission introduces } \\
\text { RPS and controls all aspects of the }\end{array}$ & $\begin{array}{l}\text { No plebiscite. New statutory body } \\
\text { has powers to act. }\end{array}$ \\
\hline
\end{tabular}

Sources: Western Mail (Perth) 18 March, 1920, p. 8; The Mercury (Hobart, Tas), 30 August 1922, pp. 5-6; Fyfe, Gentlemen's Agreements: p. 116; E. C. Dyason, “BAWRA”, , pp. 59, 66; Higgins, Sir John (1925), Address on regulation and stabilisation of wool values to Conference of Woolgrowers held in Melbourne 23 June 1925 (privately published); Higgins, Sir John (1931), The stabilisation or the equalisation or the insurance of wool values, address delivered to The Empire Wool Conference, Melbourne 22 June 1931 (privately published); Commonwealth of Australia (1932) Report by Commonwealth Wool Inquiry Committee, Commonwealth Parliamentary Papers, 1932/34, IV, paragraphs 255-58; McCarthy, Wool Disposals 1945-52, 129 and Appendix 5, pp. 164-72; Hitchins, Tangled Skeins, p. 169; F. E. Hitchins, Skeins Still Tangled, p.99; Sturgess, “The Wool Board's second Report”; Massy, Breaking the Sheep's Back, chs 5, 8. 